\title{
A Study on Higher Tourism Education Training Status and Development Strategies
}

\author{
Wu Min \\ Foreign Language School, ECJTU \\ Nanchang, Jiangxi, China \\ shirleywm@163.com
}

\begin{abstract}
To make the tourism industry develop rapidly, based on the general research on training of the higher tourism talents, the thesis analysis the status and problems, then probes into the countermeasures of higher tourism education in talents' training.
\end{abstract}

Keywords- higher tourism education, development, training status, problems, countermeatures

\section{INTRODUCTION}

In the new era, the competition among countries is inevitably the competition for talents in the tourism industry. It is of eminent importance to optimize higher tourism education, vigorous tourism talents' training strategy, comprehensively improve the quality of travel talents' skills, so as to promote rapid, sustained and healthy development of the tourism industry. This can also have a very important and far-reaching significance for the tourism industry actively takes part in the international competition for larger tourism market. According to the new requirements of the domestic and international new trend in tourism development as for personnel training, Chinese tourism's objectives and mode of training should be transferred accordingly, for example: making full use of high technology and advanced science to reform a kind of innovation and promote qualified and extraordinary education.

Compared with some developed countries of European and American, whose higher tourism education has formed their own unique featurel in cultivating tourism talents, China has still lagged behind in forming our own tourism education of Chinese characteristics. So it is urgent for us to enhance the higher tourism education system so that the quantity and quality of talents, as well as its structure and layout can adapt to China's tourism industry, which can provide lots of talents and offer intellectual supports to make us a strong tourist country in the world.

\section{ANALYSIS OF HIGHER TOURISM EDUCATION TRAINING DEVELOPMENT IN CHINA}

Although China's Tourism Education has started late, it develops rapidly. At the very first, only eight colleges set up tourism departments, till now, even any local institutions may have been offering some of the ministries of tourism institutions. In 1979, China's first tour colleges Shanghai Higher School of Tourism was established. In 1982, the former Hangzhou University, tourism majors appeared in Department of Economics, which represents the formation of China's higher tourism education system began. By the great support and investment of Chinese government, China National Tourism Administration exerts 193 million Yuan investment on education in the following years, which accounted for $9.3 \%$ of the allocation on our infrastructure at that stage. In 1990, the national tourism education investment was about 0.2 billion Yuan, accounting for more than half of the total investment on our infrastructure. Besides the financial support of the government and CNTA, the National Tourism Education Council held a work conference on the deployment of the national tourism education and training from 1980 to 1986. From 1993 on, tourism education in our country got a fairly quick development than ever before. By the end of 1990s, there were more than 138 Higher Tourism Center Schools, with the number of students over 140 thousand. Till now, the number of tourism colleges and universities is over 700 colleges and universities, with more than 600 thousand students.

At present, most provinces, autonomous regions and municipalities have established tourism institutions, with more than 20 majors. In the 30 years of development process of tourism education, the national tourism institutions have cultivated tourism talents more than one million for the travel industry. After 20 years of development, China's tourism education has basically been formed into secondary vocational education, specialist (including vocational), undergraduate, graduate, offering nearly 100,000 talents of different levels per year for the tourism industry directly [1].

\section{The Problems EXISTING IN Higher TOURISM EDUCATION TRAINING}

In recent years, due to the rapid social needs of tourism talents, various levels of tourism institutions and colleges appeared. This brings many problems:

\section{A. The Problems in Training Objectives}

Training objectives, the guiding light of education, is of eminent significance for all the higher tourism training. Distinctive, clear and sustainable training objectives are important for higher tourism education institutions of various levels. Till now, there are some tourism institutions with very small scale, limited divisions and vague objectives which may make the training alienated, bounding their eyesight and knowledge. Some even lose contact with the society, and don't care about the current status of the development of tourism and the demand of tourism markets. Many of them are blind about their distinctive features, so they follow the suits. This may 
result in a lack of regulation of professional settings and curriculum system, flexibility, adaptability and etc.

\section{B. The Problems in Training Modes}

According to tourism researchers, the requirement for the proportion of higher talents in tourism is about $2 \%$, the middle covers $18 \%$, the elementary about $80 \%$. It means that more excellent front-line talents are needed in tourism field that are able to offer services with perfect stills; besides that, some pioneering high-level talents to conduct business management are also required. But by the end of last century, it was $45.5 \%$ of the students study for Bachelor or Master Degrees in tourism and 54.4\% for the two-or-three-year diploma or certificate [2]. Compared the above 2 groups of data, we can easily find that our education mode is not in accordance with the requirements of the society and is apparently unreasonable.

Tourism is a comprehensive and Interdisciplinary major which is like the furnace of various disciplines, for example, we can find some disciplines of dissertations in TABLE I:

TABLE I. MAIN DISCIPLINES OF DISSERTATIONS.

\begin{tabular}{|l|l|}
\hline Discipline & number \\
\hline Economics & 40 \\
\hline Anthropology & 25 \\
\hline Geography & 24 \\
\hline Recreation & 23 \\
\hline Business Administration & 11 \\
\hline Education & 9 \\
\hline Sociology & 7 \\
\hline Urban-Regional Planning & \\
\hline Political Science & 5 \\
\hline Fine Arts & 1 \\
\hline Social Work & 1 \\
\hline Theology & 1 \\
\hline History & 1 \\
\hline Mass Communication & 1 \\
\hline Public Relations & 1 \\
\hline Total & 157 \\
\hline
\end{tabular}

\section{IV.COUNTERMEASURES FOR HIGHER TOURISM} EDUCATION TRAINING

\section{A. Involvement of Government Administration}

Currently, China's higher tourism education is lagged behind the foreign countries and the guidance function is the prime factor needed to be perfect. We should rely on functions of the government of each level, tourism administrative department, educational authorities and related associated units to formulate policies and regulations for the higher universities and enlarge investment on the construction of higher tourism education so as to make higher tourism education become standardized. In this process, the state and local government, together with tourism administrative departments should play the guiding role which can be illustrated as follows:

- Strengthening macro-management. There exist a few higher tourism institutions with poor teaching conditions, vague education objectives, deficient teaching faculties, irrational disciplines and courses. For new tourism institutions, the government concerned and educational authorities should carry out scientific proof and go through rigorous procedures to its approval, establish rational educational standards, control the number of professional institutions in tourism management.

- Analysis of the society needs. "The market requires a higher quality of staff as a result of the development of global tourism. Therefore, higher tourism education is required to meet this demand"[3]. The education authorities, tourism administrative departments should make comprehensive and detailed analysis of the need of tourism talents in the society, including the total number, specialized professions, required disciplines, quality structures and etc., and then provide information of talents resources to tourism colleges and universities. Accordingly, make reasonable school construction schedule and development planning. Meanwhile, put forward requests for tourism institutions about training objectives, discipline arrangements, enrollment size, training base, teaching facilities, and etc.

- Comprehensive assessment of teaching quality. The effectiveness of higher tourism education is decided by comprehensive factors, such as: students, school, tutor and etc., and there is still lack of related policies and regulations [4]. It is of vital importance to have regular and scientific comprehensive assessment of teaching condition, training base, scientific research capacity, teacher' professional competence, students' acquired skills and etc.

- Increasing investment on higher tourism education. Government of Greece doesn't permit setting up higher education privately, so, textbook and other teaching materials in higher tourism institution are all provided by the government complementarily [5]. The government of Ireland also plays the role of cooperator and operator, and exerts great energy, such as human resource, financial support and physical assistance.[6]The national and local government, department in charge of tourism development, and education authorities in China should rationalize capital investment on professional construction, especial in supportive of the specialized and distinctive disciplines and curriculums.

\section{B. Innovation of the Training Mode}

- Schools joint mode. A large number of tourism institutions and universities nowadays adopt Chinese-Chinese and Chinese-foreign joint education mode, with the latter one being more favorable. This phenomenon is common in foreign countries, For example: the Kenya government spent 200 million dollars each year in sending students for overseas study.[7]This allows the students going abroad to study and train themselves after several years learning tourism theories in native country, which may offer chances for our students to get touch with fresh knowledge, gain international experience, and 
even pursue advanced study. Meanwhile, this mode can also provide training opportunities for our teaching faculty abroad and introduce foreign prominent professional professors to our tourism institution with advanced materials, theories, ideas, and methods.

- Business-oriented mode. Business-oriented mode refers that the enterprises, in the name of the corporation and industry, set up or finance higher tourism institutions which offer talents for the enterprises. This means that the schools are in conjunction with and belong to the enterprise, therefore, the teaching objective, curriculum arrangement and etc. should be negotiated and coordinated with corporate-owned educational management departments.

- Cooperative mode. In order to meet the needs of society, the form of colleges cooperated with enterprises was born. The core is strengths Complement, resource sharing, the implementation of combining of production and training, and promoting the development of higher education institutions and enterprises [8].

\section{Strengthening Training of Tourism Talents}

Up to now, the paper has had discussed the general countermeasures about strengthening higher tourism education from a macro perspective. However, specific measures are of equal importance and necessity for higher tourism talents' training.

- Innovating Education Concept

Tourism education concept is one question from philosophy aspect, mainly covers education objectives, ideals, hierarchy structures, talents training features, which may play a guiding role in the professional training practice. By introducing new concept, it can open their institution to the outer world and refresh the out dated teaching ideals.

A clear tourism training hierarchy structure can not be neglected as well. Skilled talents are from specialist training which conducted by secondary tourism schools or specialized academy; technical talents and managers have received undergraduate studies offered by higher institutions or universities; senior management talent, high-level academics or researchers are mainly those who have received masters' and doctors' training .This can be shown in following figure:

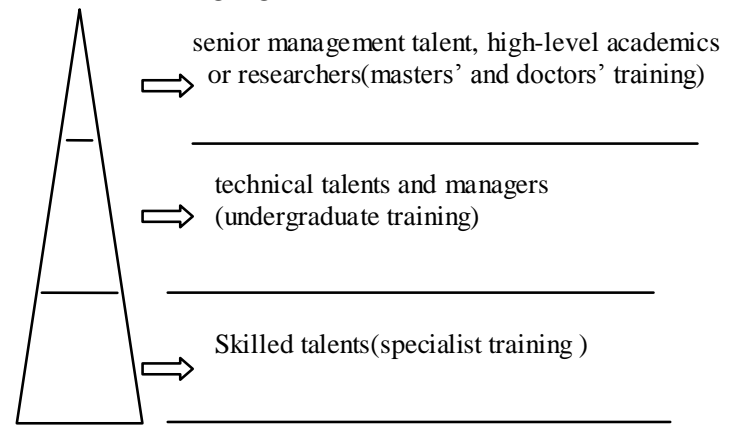

Figure 1. Hierarchy Structure of Tourism Training

- Strengthening Curriculum Construction
Curriculum construction is the core factors of higher tourism education, which play vital role in developing qualified professional tourism talents. The Curriculum arrangement should be based on the needs of the market and the distinctive features of the school under the principle of the overall standardization, optimization, operability and etc.

- Intensifying Practice Training

Theory study should be associated with practical operation. Many developed countries put emphasis on the practical training. For example, the courses of theory and practice are half in French and Swiss tourism institutions. We can draw these advanced lessons from abroad.

Practice training should not bound in the school laboratory or based solely on practice after graduation, but also can be held in some tourism enterprises such as travel agency, hotels, restaurants, scenic spot, and etc. throughout most of the professional courses. Wang (2004) bases on the experience of European countries and America, introduces case teaching method to Chinese higher tourism education, which aims at advocating tourism practice training quality [9]. The students also need to conduct the practice report, including the analysis of strengths or weaknesses of that enterprise, feelings toward training and suggestions at the end of the practice training.

- Improving Training Condition

Almost all the laboratory and teaching instruments of higher tourism institution in the USA are equipped with the latest upscale products, which quarantine the hard resource for teaching[10].Just as one can't make bricks without straw, teaching can not be perfect without good training condition, such as teaching materials, teaching staff and method, which are carries to achieve good higher tourism education. Therefore, it is imperative to implement the reform of the status.

\section{CONCLUSION}

By collecting the information of tourism institutions, college students, graduates and teachers of various regions of China, and analysis the development of higher tourism education as well as its status nowadays, especially the problems facing our talents' training, this paper put forward some countermeasures for the improvement of higher tourism education from four aspects. Further detailed research is needed in this field. As China's higher tourism talents' education is on a relatively new stage, its academic construction, developing measures are still some open questions. Although the paper was carefully formatted, the generalizations of the findings must proceed with caution because of the cost and time limitations. So, inevitably, there may be some problems and shortcomings in this article, and I hope experts and professors would help me perfect this paper!

\section{REFERENCE}

[1] W.Bihu and L.Xiaoxiao, A Research on Higher Tourism Education in China, TOURISM TRIBUNE,1st ed., vol.2.China: Beijing, 2005, pp.9-15

[2] T.Lam and H. Xiao,Challenges and constraints of hospitality and tourism education in China, International Journal of Contemporary Hospitality Management, 5th ed, vol.12. 2000,pp:291-295.

[3] Z.Pingping. Analysis of Higher Tourism and Hospitality Education in China, Overseas English, 2nd ed., vol 12. China, 2011,pp:81-84 
[4] D. Leslie and A. Richardson, Tourism and Cooperative Education in UK undergraduate courses:are the benefits being realised,Tourism Management,UK :vol21.2000, pp:489 498.

[5] S .Evangelos Christou, Hospitality Management in Greece:An Exploratory Study Tourism Management, 6th ed.,vol 20. Greece ,1999,pp:683 691.

[6] J .Deegan, A Long-Term Perspective on Irish Tourism Policy. In Proceedings of Tourism and Hospitality Research., Portrush :University of Ulster, 2005.

[7] M.A. Mayaka, An International Handbook of Tourism Education, Oxford : Elsevier,2005, pp:161 171
[8] J. Peiling and L.Jun, A Study on the Level-Based Cultivation Pattern of Tourism Education Based on the Demands for Human Resources, TOURISM TRIBUNE,7th ed., vol 57. China:Beijing,2005,pp.57-61.

[9] M. Wang, Study on the Introduction of Case Teaching Method in European and American, MBA Program to Tourism Management Education in China, Journal of Tianjin University of Cmmerce, 6th ed. Vol 24, 2004, pp:24

[10] M. Mayaka and J.S.Akama, Systems Approach to Tourism Training and Education :The Kenyan Case Study, Tourism Management, 7th ed.,vol 28. 2007, pp:298 306 